
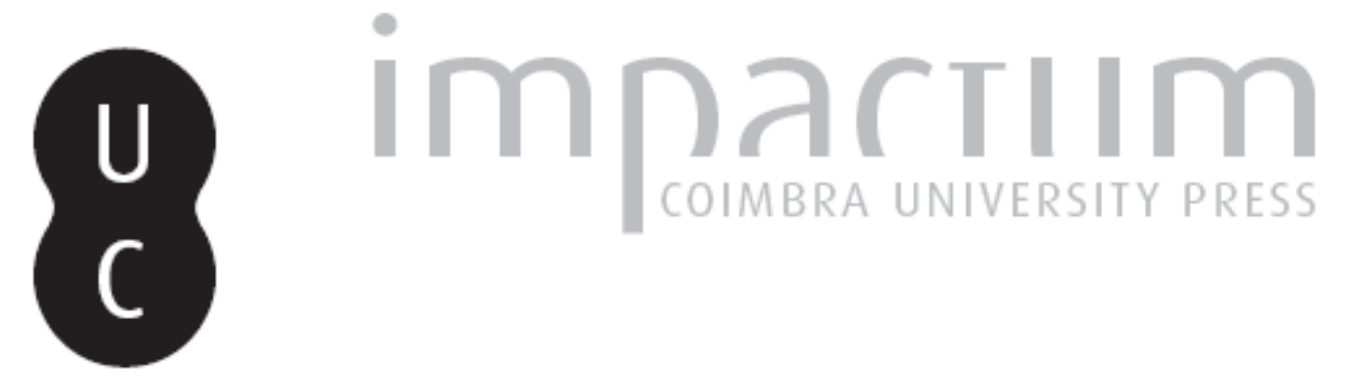

\title{
[Recensão a] Giambattista Vico, Ciência nova, tradução de Jorge Vaz de Carvalho, prefácio de António M. Barbosa de Melo
}

Autor(es): $\quad$ Marnoto, Rita

Publicado por: Imprensa da Universidade de Coimbra

URL persistente:

URl:http://hdl.handle.net/10316.2/42662

DOI:

DOI:https://doi.org/10.14195/0870-8584_2_24

Accessed : $\quad$ 26-Apr-2023 12:37:49

A navegação consulta e descarregamento dos títulos inseridos nas Bibliotecas Digitais UC Digitalis, UC Pombalina e UC Impactum, pressupõem a aceitação plena e sem reservas dos Termos e Condições de Uso destas Bibliotecas Digitais, disponíveis em https://digitalis.uc.pt/pt-pt/termos.

Conforme exposto nos referidos Termos e Condições de Uso, o descarregamento de títulos de acesso restrito requer uma licença válida de autorização devendo o utilizador aceder ao(s) documento(s) a partir de um endereço de IP da instituição detentora da supramencionada licença.

Ao utilizador é apenas permitido o descarregamento para uso pessoal, pelo que o emprego do(s) título(s) descarregado(s) para outro fim, designadamente comercial, carece de autorização do respetivo autor ou editor da obra.

Na medida em que todas as obras da UC Digitalis se encontram protegidas pelo Código do Direito de Autor e Direitos Conexos e demais legislação aplicável, toda a cópia, parcial ou total, deste documento, nos casos em que é legalmente admitida, deverá conter ou fazer-se acompanhar por este aviso.

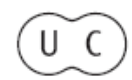




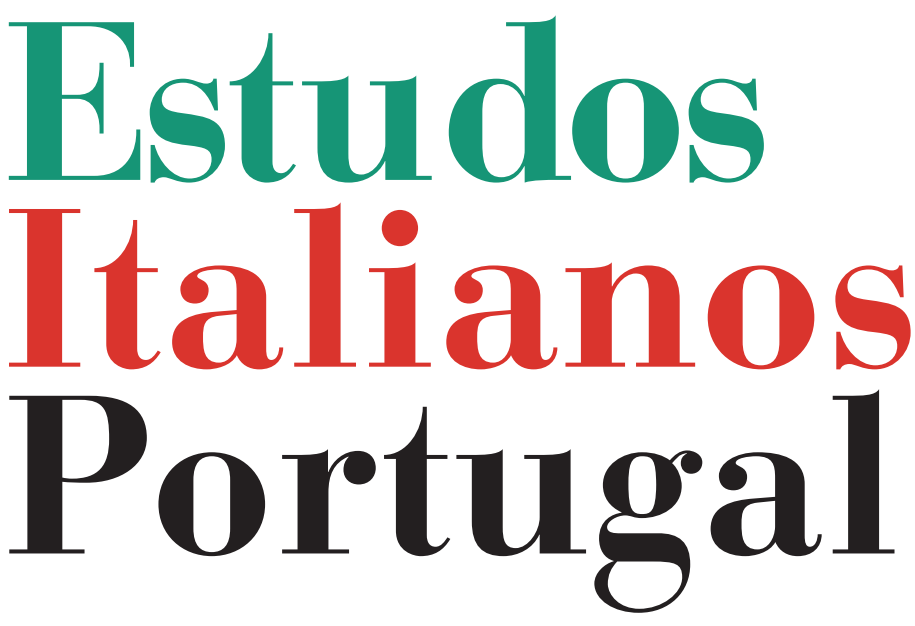

Instituto

Italiano

de Cultura

de Lisboa

Nova Série

$\mathbf{N}^{\mathbf{0}} 2$ 
Giambattista Vico, Ciência nova, tradução de Jorge Vaz de Carvalho, prefácio de António M. Barbosa de Melo, Lisboa, Fundação Calouste Gulbenkian, 2005, $\mathrm{XX}+853 \mathrm{pp}$.

Em boa hora promoveu a Fundação Calouste Gulbenkian as suas edições de "Textos clássicos" e nelas acolheu este tratado-chave da nossa cultura: "as raízes da cultura estão naquelas obras chamadas clássicas, obras cuja mensagem se não esgotou e permanecem fontes vivas do progresso humano", lê-se na contracapa. É num programa concebido a partir dessas orientações que se enquadra a Ciência nova, a obra-prima do pensador napolitano Giambattista Vico (1668-1744).

Giambattista Vico é o mais genial expoente daquele interesse pela recuperação da memória que caracteriza a Itália de inícios do século XVIII. Distancia-se do método matemático e de Descartes, na convicção de que o homem apenas pode conhecer aquilo de que é artífice, ou seja, a história. Cabe-lhe, por isso, um lugar de precursor na definição do seu campo disciplinar autónomo. É nas páginas da Ciência nova que lança os grandes princípios dessa metodologia. Associa a filosofia, que considera "ciência do verdadeiro", à filologia, "consciência do certo". Desta feita, a Ciência nova "coloca a história humana sob o signo da Liberdade e do Direito, recusando-se a aprisionar as ideias num qualquer sistema de referência, ou paradigma, assente no acaso ou na fatalidade", conforme escreve Barbosa de Melo ao terminar o prefácio à tradução portuguesa. Vico abre a história ao mundo do homem e à sua actuação no curso da própria história. Assim se compreende que, desde o século XVIII até aos nossos dias, a Ciência nova tenha vindo a ser ponto de referência obrigatório para uma reflexão teorética que se alargou, do campo da história, ao do direito, da filosofia, da literatura e, mais recentemente, ao das ciências sociais.

A ausência de uma tradução para português era lacuna que há muito latejava e que foi finalmente preenchida. Mas não é esse o único mérito desta empresa. A linguagem do original caracteriza-se por marcas históricas muito fortes e é veículo de uma elaboração conceptual densa, 
que ocupa um número de páginas não irrelevante. Foram estas as dificuldades, que não são de somenos, que Jorge Vaz de Carvalho enfrentou. Optou por uma modalidade translativa segura, acompanhando o original italiano de forma próxima e precisa. O trabalho de tradução brilha na fluidez com que é dada a palavra a Vico. A concatenação entre períodos, estruturas sintácticas e formulações lexicais reflecte o andamento do texto italiano. A tradução dirige-se a destinatários com interesses culturais muito específicos. Ora, essa veste linguística põe à disposição do leitor português uma versão que leva consigo marcas de formas de organização discursiva e lucubrativa dotadas de forte identidade, trazendo para o nosso tempo os conotados históricos próprios da linguagem de Vico. A fidelidade aos níveis sintáctico e lexical reverte a favor da exactidão e da clareza da terminologia utilizada, dado que se recorre ao vocabulário do pensamento conceptual.

Esse equilíbrio pressupõe a ponderada renúncia a uma proliferação de recursos que seria desadequada, além do mais, ao seu enquadramento pragmático.
A terminologia utilizada revitaliza, não raro, estratos da língua portuguesa que se encontravam adormecidos. Servem-lhe de contraponto os desvios a essa linha de orientação que se mostram estritamente necessários, quando a correspondente translativa próxima prejudica a intelegibilidade da frase. Se um vocábulo italiano não tem correspondente directo em português, as primeiras escolhas incidem sobre palavras formadas a partir do mesmo étimo. Se a ordem dos elementos frásicos pode prejudicar a compreensão, é sujeita a alterações adequadas.

Consagra o mérito desta Ciência nova o Prémio de Tradução Científica e Técnica em Língua Portuguesa que lhe foi atribuído pela União Latina e pela Fundação para a Ciência e a Tecnologia, na sua XIV edição, de 2006. RITA MARNOTO

Maria José de Lancastre, Con un sogno nel bagaglio. Un viaggio di Pirandello in Portogallo, $\mathrm{Pa}-$ lermo, Sellerio, 2006, 195 pp.

Por iniciativa de uma jovem e dinâmica editora da capital da Sicília, acaba de ser publicada 